\title{
The Mediating Role of Organizational Citizenship Behaviour (OCB) on the Effect of Work Culture and Leadership Style on Employee Performance (Study at the Department of the PU Resources of the Air to the West Is East)
}

\author{
Mahmudah Enny Widyaningrum \\ Faculty of Economics and Business, University of Bhayangkara Surabaya
}

\begin{abstract}
The objective of this study is to assess the mediating role of Organizational Citizenship Behaviours (OCB) on the effect of work Culture and Leadership style on Employee Performance. This study using explanatory method, with 147 respondents sample of employee of the Public Services Office of Water Resources. The results shows that both work culture and leadership style had a positive influence on OCB. Likewise, employee performance is positively influenced by work culture and leadership style. Also, OCB mediates the positive effect of Work culture and leadership on employee performance. The result shows support the hypothesis. The higher the level of contribution made by employees in carry out the behaviors and effective leadership, the higher the performance achievement.
\end{abstract}

Keywords: Work culture, leadership style, OCB, Performance

DOI: $10.7176 / \mathrm{EJBM} / 12-23-06$

Publication date:August $31^{\text {st }} 2020$

\section{Introduction}

The demands of the organization to realize Good Governance in fulfilling public services have not been able to achieve optimal results. Good corporate governance is a system that regulates the relationship between stakeholders (shareholders, company management, creditors, government and other related parties) who have certain rights and obligations to the company. According to Monks and Minow in Kaihatu (2006), Good Governance (GCG) is definitively a system that regulates and controls an organization that creates added value (value added) for all parties.

Changes in an organizational system that are clean and authoritative (good governance) will be able to realize the fulfillment of society in a good, efficient, effective and quality manner. Of course, it needs to be supported by employees who are professional, fair, honest and responsible, competent in their fields and produce high performance.

Changes in an organizational system that are clean and authoritative (good governance) will be able to realize the fulfillment of society in a good, efficient, effective and quality manner. Of course, it needs to be supported by employees who are professional, fair, honest and responsible, competent in their fields and produce high performance.

Performance is the result of work achieved by employees. Mangkunegara (2018) states that performance is the result of work that can be achieved by employees both individually and in groups in an organization, in accordance with the authority and responsibility given by the organization in an effort to achieve the vision, mission and goals of the organization concerned by stating the ability, persistence, independence, ability solve problems according to the time limit given legally, do not violate the law and in accordance with morals and ethics. Tannandy (2018), states that performance is the result of work in quality and quantity that an employee wants to achieve in carrying out his duties with the responsibilities assigned to him. The results of improving one's performance cannot be separated from the strength of the employees based on the habitual patterns of behavior in doing work with a high work culture, and which are embedded in the employees for whom they are responsible. Work culture is a pattern developed by employees in encouraging a form of stability when carrying out their duties to increase activities or activities that are manifested by behavior, values and norms in work life both individually and in collaboration in groups so as to produce high performance (Rachman, 2015). 2017). Khuzaeni and Solimun (2013) stated that building a strong work culture to reduce job stress and increase job satisfaction which in turn improves employee performance. Work culture is a set of behavior patterns that are inherent as a whole in the area of every individual in an organization, building a culture means enhancing and maintaining positive sides, and trying to get used to certain behavior patterns in order to create a new, better form.

Work culture, is a set of behavior patterns that are inherent as a whole in every individual in an organization. Building a culture also means increasing and maintaining positive sides, and trying to get used to certain patterns of behavior in order to create a new, better form. Robbins and Judge (2017) state that work culture in an 
organization refers to a system of shared meanings held by members that distinguishes the organization from other organizations. Therefore, the success of an organization in improving the government system with good governance depends on the organizational leadership style. A transformational leadership style is a form of leadership that is able to arouse or motivate subordinates, so that the activities carried out by employees are able to produce good achievements, at least able to achieve high performance, are considered to be more than what they previously thought (Rachman, 2020). Kho et al. (2019) that leadership style is a set of characteristics used by leaders to influence subordinates so that organizational goals are achieved or it can also be said that leadership style is a pattern of behavior and strategies that are preferred and often applied by a leader. Tambunan (2019) states that the leadership style tends to directly affect employee performance by always emphasizing that it is important to establish good relationships with subordinates. The leadership style applied in the organization is able to influence subordinates positively but the leadership is also able to motivate employee behavior in increasing the desired work results by the organization. Employee behavior as organizational citizenship behaviors (OCB) is an indication that reflects the process of forming employee behaviors in organizations that have an impact on improving individual employee performance (Widyaningrum, 2010). Individual employees who take the initiative to go beyond their normal roles and job descriptions (OCB) are essential in higher institutions for university quality outcomes and effectiveness (Hazratian et al., 2015). Meanwhile, Podsakoff et al. (2000), that colleagues summarize organizational citizenship behavior that affects organizational performance by increasing the efficiency of colleagues and managers, increasing the effective use of resources for more productive activities and purposes. Robbins and Judge (2017), state the fact that organizations that have employees who have good OCB (Organizational Citizenship Behavior) will have better performance than other organizations. In the study of these problems, there is a follow-up to understand the behavior of employees in the organization so that the researcher compiles a formula proposed in the study as follows;

1. Does work culture affect organizational citizenship behavior?

2. Does leadership style affect organizational citizenship behavior?

3. Does work culture affect employee performance?

4. Does leadership style affect employee performance?

5. Does organizational citizenship behavior affect employee performance?

6. Does organizational citizenship behavior mediates the effect of work culture on employee performance?

7. Does organizational citizenship behavior mediates the effect of leadership style on employee performance?

\section{Literature Review}

Work culture

Work culture is a form of pattern of behavior of people in the organization by referring to the system applied by the organization to change and improve work performance which is associated with the values, norms and rules that become its beliefs. Nurhadijah (2017), that the work culture of employees is quite good in the role of education providers which can be seen from mutual respect and high cooperation among employees. According to Schermerhorn (2003), work culture is a system of spreading jobs and beliefs and values that develop within the organization and directing the behavior of organizational members. The successful behavior of organizational members that becomes habitual will be related to the quality of work where the cultural values, norms and rules of the members become their beliefs and become habits in behavior. Based on the habitual patterns of behavior of each individual or group cultivated in an organization, several indicators are needed as an assessment of habits in behavior, including discipline, openness, mutual respect and cooperation (Nurhadijah, 2017).

\section{Leadership Style}

The success of a business is not only supported by employees who have quality skills in carrying out their duties. However, this depends on a leadership pattern or style that adheres to the principles, of course every movement and decision will greatly affect the sustainability of the activities of its members in the organization. Leadership style is a set of characteristics used by leaders to influence subordinates (Rivai, 2014). Leaders should understand that success in improving performance and productivity must involve employees because employees are not only the main force in bringing about change, but also more actively participate in planning change in the organization (Robbins, 2014). Therefore, leadership style is a preferred pattern of behavior and strategy and is often applied as leadership in organizations. Some leadership indicators that are often used as a leadership style in an organization include authoritarian leadership, participatory leadership and delegative leadership (Hasibuan, 2016).

\section{Organizational Citizenship Behavior (OCB)}

Organizational Citizenship Behavior (OCB) is an extra insider individual behavior, which is not directly or explicitly recognizable in a formal work system, and which in aggregate can increase the effectiveness of organizational functions (Nielen, 2012). Organizational Citizenship Behavior is an individual behavior that contributes to the creation of organizational effectiveness and is not related to organizational reward systems 
(Kumar et al., 2009). Whereas Organ (1988) states that individual behavior is discretionary, not directly or explicitly recognized by formal reward systems, and that in aggregate it promotes effective organizational functions. Organ (1997) further states that, OCB as a voluntary behavior, individual choice and initiative are not directly related to the formal reward system of the organization, but as a whole can increase organizational effectiveness. besides OCB also involves several elements of behavior such as helping others, volunteering for additional tasks, and complying with workplace rules and procedures. This behavior is constructive, meaningful and positive social behavior (Agustiningsih et al., 2016). Alkahtani (2015) states that one of the main reasons why OCB has attracted the attention of many academics and practitioners is because of its proven significance to organizational effectiveness. Therefore, successful organizations require organizational citizenship (employees) who want to carry out more than just ordinary tasks but will give employees performance that exceeds expectations. Several indicators are used in determining employee assessments of organizational citizenship behavior through altruism, civic virtue, conscinetiousness, coutesy and sportmanship.

\section{Performance}

Performance is the result of work in quality and quantity that an employee wants to achieve in carrying out his duties in accordance with the responsibilities assigned to him (Tannandy, 2018). Furthermore, Mangkunegara (2017) states that performance can be divided into 2 (two), namely individual performance and organizational performance. Meanwhile, Busro (2018) states that the performance or work that can be achieved by a person or group of people in a company is in accordance with their respective authorities and responsibilities in an effort to achieve company goals legally, does not violate the law and does not conflict with morals or ethics. In other words, performance is the result of work that can be achieved by employees, both individuals and groups in an organization in accordance with the authority and responsibility given by the organization in an effort to achieve the vision, mission and goals of the organization concerned by including the ability, perseverance, independence, ability to solve problems. within the limits given legally, does not violate the law and is in accordance with morals and ethics. Kho et al. (2019), that performance is the result of work achieved by a person based on job requirements, requirements can be called work standards, namely the level that is expected for a certain job to be completed and compared to the goals or targets to be achieved. Therefore, a good performance assessment can be measured by the quality of work, quantity of work, timeliness, effectiveness, independence and work commitment (Robbins and Judge, 2019).

\section{Conceptual Framework and Hypotheses}

The conceptual framework model of this research is formed based on the problems and problem formulations proposed so that it can make it easier to understand the problems that occur in the organization of the Public Works Department of Water Resources, East Java Province in Sidoarjo. The following is an image model of the research conceptual framework as below:

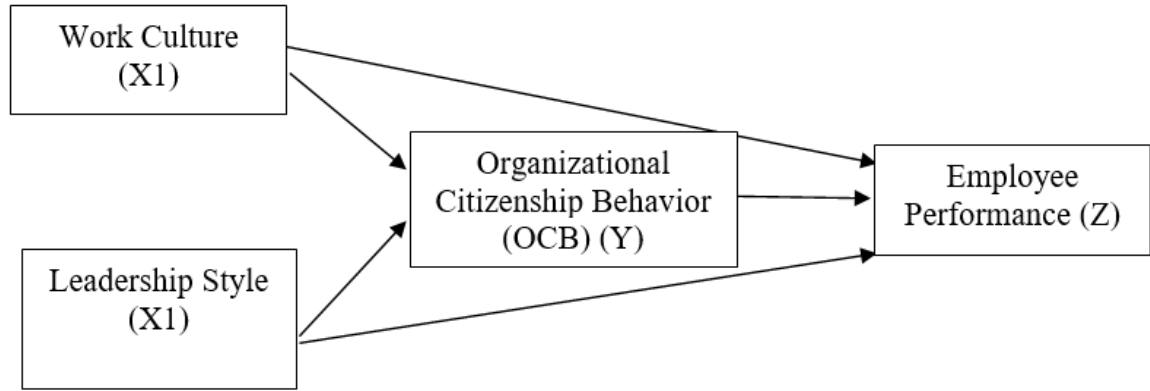

\section{Figure. 1 Conceptual Framework Research}

Based on the conceptual framework model, the following hypotheses are formed:

1. Work culture affects organizational citizenship behavior.

2. Leadership style influences organizational citizenship behavior.

3. Work culture affects employee performance.

4. Leadership style affects employee performance.

5. Organizational Citizenship Behavior affects employee performance

6. Organizational Citizenship Behavior mediates the effect of work culture on employee performance

7. Organizational Citizenship Behavior mediates the effect of leadership style on employee performance.

\section{Research Methods}

\section{Research Design}

The type of research used is a development model or design that results from the relationship between variables using the sampling technique. This research design details the important procedures for obtaining the information 
needed in compiling and / or solving research problems (Rachman, 2018). This research design is an explanatory research type; This means that it aims to analyze the relationship between constructs (variables) or how one construct affects other constructs, because this study aims to explain the causal relationship between constructs through hypothesis testing.

\section{Population and Sampling Techniques}

Population is the total or the number that is on the subject studied but includes all employees in the Public Works Office. Water Resources of East Java Province in Sidoarjo are 147 employees. The sampling technique used stratified random sampling, that the population and sample for employees in this study were heterogeneous and limited in number of populations, so the sampling technique used was saturated samples (Rachman, 2018).

\section{Data analysis technique}

For the analysis technique using path analysis, namely testing the structural model, and testing research instruments and testing between variables using the $t$ test.

\section{Results and Discussion}

The results of the analysis of this research instrument have determined the items of each indicator that are estimated to be valid (valid) to measure the tested variables and provide precise measurement results as shown in the table below

\section{Table 1. Validity Test Result}

\begin{tabular}{|c|c|c|c|c|c|c|}
\hline \multirow[b]{2}{*}{ Variable } & \multicolumn{5}{|c|}{ Corrected Item-Total Correlation } & \multirow{2}{*}{$\begin{array}{l}\text { Cronbath Alpha } \\
0,05\end{array}$} \\
\hline & $\mathrm{X} 1$ & $\mathrm{X} 2$ & $\mathrm{Y}$ & $\mathrm{Z}$ & Keterangan & \\
\hline \multirow[t]{4}{*}{ Work Culture } & 0.789 & & & & Valid & 0,792 \\
\hline & 0.399 & & & & Valid & \\
\hline & 0.449 & & & & Valid & \\
\hline & 0.813 & & & & Valid & \\
\hline \multirow[t]{3}{*}{ Leadership Style } & & 0.632 & & & Valid & 0,796 \\
\hline & & 0.682 & & & Valid & \\
\hline & & 0.615 & & & Valid & \\
\hline \multirow[t]{5}{*}{$\begin{array}{l}\text { Organizational } \quad \text { Citizenship } \\
\text { Behavior }\end{array}$} & & & 0.759 & & Valid & 0,621 \\
\hline & & & 0.511 & & Valid & \\
\hline & & & 0.455 & & Valid & \\
\hline & & & 0.742 & & Valid & \\
\hline & & & 0.466 & & Valid & \\
\hline \multirow[t]{6}{*}{ Employee Performance } & & & & 0.395 & Valid & 0,676 \\
\hline & & & & 0.434 & Valid & \\
\hline & & & & 0.785 & Valid & \\
\hline & & & & 0.544 & Valid & \\
\hline & & & & 0,422 & Valid & \\
\hline & & & & 0,774 & Valid & \\
\hline Critical Value $\alpha=0,05$ & & & & & $\begin{array}{c}> \\
0,30\end{array}$ & 0,60 \\
\hline
\end{tabular}

Source: primary data processing results

Based on the results of the validity test in Table 1, it is stated that the overall indicators of the research variables used show validity results, because all correlation coefficients of the total item correlation numbers are greater than the critical value of 0.30 . This means that all variable indicators tested as research instruments can be accepted. While reliably all items are declared reliable or have the ability with a reliability level of more than 0.60 so that the questionnaire used is feasible to continue for research dissemination.

\section{Path Analysis Results}

This study uses path analysis to see the effect of work culture and leadership style on employee performance through OCB at the Public Works Department of Water Resources, East Java Province in Sidoarjo as shown in the following table; 
Table 2. Path Analysis Result

\begin{tabular}{|c|c|c|c|c|}
\hline Model & Path Coefficient (beta) & $\mathrm{t}$ & Sig. & $\mathrm{R}^{2}$ \\
\hline \multicolumn{5}{|c|}{ Sub Structural 1 ( $X_{1}$ dan $X_{2}$ ke $\left.Y\right)$} \\
\hline Work Culture & 0,547 & 7,178 & 0,000 & \multirow[t]{2}{*}{0,565} \\
\hline Leadership Style & 0,615 & 8,061 & 0,000 & \\
\hline \multicolumn{5}{|c|}{ Sub Struktural $2\left(X_{1}, X_{2}\right.$ ke $\left.Z\right)$} \\
\hline Budaya Kerja & 0,499 & 6,275 & 0,000 & \multirow[t]{2}{*}{0,526} \\
\hline Gaya Kepemimpinan & 0,617 & 7,746 & 0,000 & \\
\hline \multicolumn{5}{|c|}{ Sub Structural 3 (Y ke Z) } \\
\hline OCB & 0,992 & 69,592 & 0,000 & 0,984 \\
\hline
\end{tabular}

Source: primary data processing results

Based on Table 2 above, it can be seen that the standardized coefficients beta of the work culture variable (X1) is 0.547 with a significant level of 0.000 , this means that work culture (X1) has a positive and significant direct effect on OCB (Y). Likewise, the standardized coefficients beta of the leadership style variable (X2) is 0.400 with a significant 0.000 , this means that the leadership style (X2) has a positive and significant direct effect on OCB (Y). Similarly, it is shown that the standardized coefficients beta of the work culture variable (X1) is 0.499 with a significant level of 0.000 , this means that work culture $(\mathrm{X} 1)$ has a positive and significant direct effect on employee performance (Y). Likewise, the standardized coefficients beta of the leadership style variable (X2) is 0.615 with a significant 0.000 , this means that the leadership style (X2) has a positive and significant direct effect on employee performance (Y). Furthermore, standardized coefficients beta variable OCB (Y) is 0.617 with a significant 0.000 , this means that $\mathrm{OCB}(\mathrm{Y})$ has a positive and significant direct effect on employee performance (Z).

Based on Table 2, it can also be seen that the path of indirect influence by calculating the influence of work culture variables on employee performance through OCB, and leadership style influencing employee performance through OCB, the results can be shown in the table below;

Table 3. Direct Effect and Indirect Effect

\begin{tabular}{|l|l|l|}
\hline \multicolumn{1}{|c|}{ Variable } & Indirect Effect & Indirect Effect \\
\hline Work Culture $\rightarrow$ OCB & 0,548 (sig.) & \\
Leadership Style $\rightarrow$ OCB & 0,615 (sig.) & \\
Work Culture $\rightarrow$ Employee Performance & 0,499 (sig.) & 0,544 \\
Leadership Style $\rightarrow$ Employee Performance & 0,617 (sig.) & 0,610 \\
OCB (Y) $\rightarrow$ Employee Performance (Z) & 0,992 (sig.) & \\
\hline
\end{tabular}

Source: primary data processing results, (Sig.) = alpha significance 0,05

The meaning of calculating the direct and indirect effect is to determine the function or role of the intervening variable in this study is OCB (Y), does it strengthen the influence in the relationship between work culture variables and leadership style on employee performance through OCB in the Provincial Water Resources Public Works Service. East Java in Sidoarjo.

The results of the path analysis can be described as a whole which explains the influence between work culture (X1) and leadership style (X2) on OCB (Y) and employee performance (Z), which is shown in the figure below.

\section{Hypothesis Test Results}

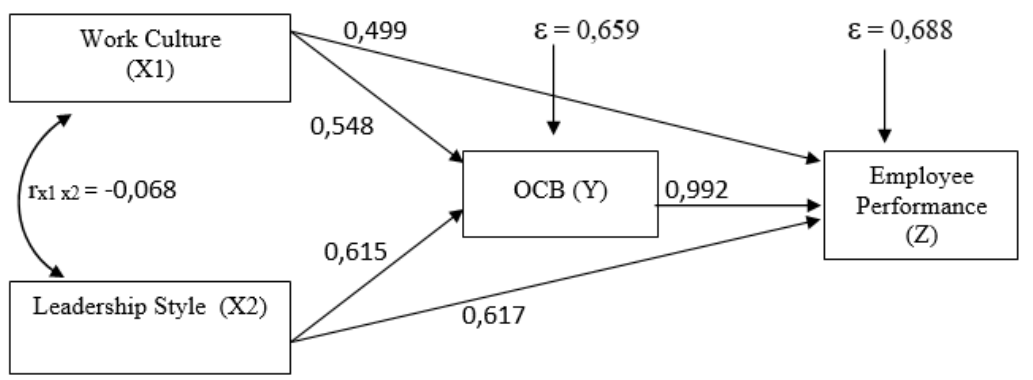

Figure. 2. Path Analysis Result

Based on Figure 2, the test results can be analyzed as follows:

1. Work culture has a positive and significant effect on employee OCB, accepted. The results obtained on the path coefficient of the work culture variable on the OCB variable $(Y)$ indicate that the more work culture increases in understanding the problems faced in the work environment, the better OCB of employees at work.

2. Leadership style has a positive and significant effect on OCB, accepted. The results obtained on the variable 
path coefficient of leadership style to the OCB variable (Y) indicate that the better the leadership style shown by the leadership of the organization in supporting the implementation of work, the better the employee's OCB.

3. Work culture has a positive and significant effect on employee performance, accepted. The results obtained on the work culture path coefficient on the employee performance variable $(Z)$ indicate that the higher the understanding of the employee's work culture which is expected to help in carrying out work, the higher the achievement of employee performance is achieved.

4. Leadership style has a positive and significant effect on employee performance, accepted. The results obtained on the variable path coefficient of leadership style that are shown effectively on the employee performance variable $(Z)$ indicate that the better the behaviors carried out in the work environment for the work problems carried out, the better the achievement of employee performance expected by the organization.

5. OCB has a positive and significant effect on employee performance, accepted. The results obtained on the OCB variable path coefficient which is shown effectively on employee performance $(\mathrm{Z})$ indicate that employees who are members of the organization have understood their identity by improving work behaviors in producing high performance in accordance with organizational goals.

6. Work culture has a positive effect on employee performance through OCB, accepted. The results obtained on the path coefficient of the work culture variable on the employee performance variable $(Z)$ have an indirect effect through OCB being able to interpret organizational membership in achieving organizational goals. This indicates that the increasing behavior of organizational members in doing work outside their respective areas of work is in accordance with the rules and habits of doing work without any pressure from the organization so that it can produce high performance.

7. Leadership style has a positive effect on employee performance through work OCB, accepted. The results obtained on the path coefficient of the leadership style variable on the employee performance variable $(\mathrm{Z})$ have an indirect effect through OCB being able to complete work well even without participatory leadership of the organization. This shows that the increasing initiative and creativity of employees without leadership direction can complete work outside of their duties. Because as a member of the organization and understanding what the organization wants, it can be responded well so that overall it can accomplish its goals.

\section{Conclusion and Recommendations}

The results of the discussion and findings in this study indicate that the work culture and leadership style in producing the achievement of completed tasks exceeds what the organization wants. This is shown by OCB which is stated as the behavior of members of the organization that is able to change high work results even without instructions from the leadership. Because the leadership only provides instructions for participating in the work, Organizational membership can produce work according to the goals the organization wants. Hence, the work or performance of employees who are part of the organizational members can easily meet organizational expectations. Therefore, it is recommended that high employee performance appraisals be significantly influenced by OCB. The influence of work culture and leadership style which has a positive important role in achieving employee performance is able to change employee behavior to be more respectful and creative in meeting organizational goals.

\section{Refferences}

Agustiningsih H. N., Thoyib A, Djumilah H. and Noermijati N (2016). The Effect of Remuneration, Job Satisfaction and OCB on the Employee Performance. Science Journal of Business and Management, 4 (6), 212-222. Desember. http://article.sciencepublishinggroup.com/html/10.11648.j.sjbm.20160406.16.html.

Alkahtani A. (2015). Organizational Citizenship Behavior (OCB) and Rewards. International Business Research, $8 \quad(4), \quad 210-222$ DOI:10.5539/ibr.v8n4p210. http://www.ccsenet.org/journal/index.php/ibr/article/download/44229/25159.

Busro, Muhammad, (2018), Teori-teori Manajemen Sumber Daya Manusia, Jakarta: Prenadamedia Group. (Google Scholar).

Hasibuan, H. Malayu S.P. (2016). Manajemen Sumber Daya Manusia. Edisi Revisi. Jakarta: Buni Aksara Bangun. (Google Scholar).

Hazratian T., Khadivi A., Abbasi B. and Ghojazadeh M. (2015). Association Between Organizational Citizenship Behavior and Educational Performance of Faculty Members in Tabriz University of Medical Sciences, Res Dev Med Educ., 4 (1), 81-84. https: DOI: 10.15171/rdme.2015.034. (https://www.researchgate.net/publication/307823792)

Kaihatu, Thomas S. (2006), Good Corporate Governance dan Penerapannya di Indonesia JURNAL MANAJEMEN

DAN KEWIRAUSAHAAN, 
http://www.petra.ac.id/ puslit/journals/dir.php?DepartmentID=MAN VOL.8, NO. 1, MARET 2006: 1-9

Khuzaeni, MS. Idrus and Solimun Djumahir (2013. The Influence of Work Culture, Work Stress to the Job Satisfaction and Employees Performance in the State Treasury Service Office in Jakarta, Indonesia. IOSR Journal of Business and Management (IOSR-JBM) Volume 9, Issue 2 (Mar. - Apr. 2013), PP 49-54. e-ISSN: 2278-487X, p-ISSN: 2319-7668. http://iosrjournals.org/iosr-jbm/papers/Vol9-issue2/F0924954.pdf.

Kho et al. (2019 Kho, Eko G.V., Irvan Trang, Yantje Uhing (2019), Pengaruh Kepemimpinan, Budaya Organisasi, dan Kompetensi Terhadap Kinerja Karyawan PT. Bank Syariah Mandiri Cabang Bitung, Jurnal EMBA, $\begin{array}{llllll}\text { Volume } & 7, & \text { No.1, } & \text { Januari } & \text { 2019, } & \text { Hal. }\end{array}$ https://ejournal.unsrat.ac.id/index.php/emba/article/download/22628/22323.

Kumar, Kuldeep, Arti Bakhshi, and Ekta Rani, 2009. Linking the 'Big Five' Personality Domains to Organizational Citizenship Behavior. International Journal of Psychological Studies. Vol. 1, No. 2. 73 81.Desember. DOI: 10.5539/ijps.v1n2p73. https:/www.researchgate.net/publication/42385721.

Mangkunegara, A.A. Anwar Prabu. (2017). Evaluasi Kinerja SDM. Bandung: Remaja Rosdakarya. (Google Scholar)

Mangkunegara, A.A. Anwar Prabu (2018) Manajemen Sumber Daya Manusia Perusahaan. Bandung: Remaja Rosdakarya. (Google Scholar).

Nurhadijah. (2017). Studi Tentang Budaya Kerja Pegawai Sekolah Menengah Kejuruan Negeri 1 Penajam Paser Utara. E-Journal llmu Administrasi Negara, Volume 5 (Nomor 1), 2017 : $5476 \quad$ - 458. https://ejournal.an.fisip-unmul.ac.id/(02-28-17-01-56-12).pdf.

Organ (1988 D. W. (1988). Organizational citizenship behavior: The good soldier syndrome. USA: D.C. Heath and Company. (Google)

Organ, D. W. (1997). Organizational Citizenship Behavior: It's Construct Clean-up Time. Human Performance, 10(2), 85-97. https://doi.org/10.1207/s15327043hup1002_2

Podsakoff P. M., MacKenzie S. B., Paine J. B., and Bachrach D. G. (2000). Organizational Citizenship Behaviors: A Critical Review of the Theoretical and Empirical Literature and Suggestions for Future Research. Journal of Management, 26 (3), 513-563. https://doi.org/10.1016/S0149-2063(00)00047-7.

Rachman, Mochammad Munir. (2017). The Influence of Work Culture on Job Satisfaction and Performance: A Study on the Employees of the Bank Jatim in Surabaya, East Java, Indonesia. European Journal of Business and Management. Vol.9, No.26. https://iiste.org/Journals/index.php/EJBM/article/view/38791/39892. (Google Scholar)

Rachman, Mochammad Munir. (2018). Metodologi Penelitian. Cetakan Kedua. Surabaya: Unipress, Universitas PGRI Adi Buana. (Google Scholar)

Rachman, Mochammad Munir. (2019). Aplikasi Komputer Statistik: Sebagai Pendekatan Untuk Analisis Data Statistik Dengan SPSS. Cetakan Ketiga. Surabaya: Unipress, Universitas PGRI Adi Buana. (Google Scholar)

Rachman, Mochammad Munir. (2020). The Influence of Transformational Leadership on the Performance of Employees with Motivation and Job Satisfaction as Intervening (A Study on the Office of the Department of Irrigation works in the District of Sidoarjo, Indonesia). Vol.12, No. 14.https://iiste.org/Journals/index.php/EJBM/article/view/52872/54631. (Google Scholar).

Rivai, Veithzal. 2014. Manajemen Sumber Daya Manusia untuk Perusahaan. Edisi Keenam. Depo: PT. Raja Grafindo Persada. (Google)

Robbins, Stephen P. (2014). Organization theory: Structure, design, and applications. New Jersey: Pearson Pentice-Hall Upper Saddle River, ISBN-13: 978-0136419457 (Google)

Robbins, Stephen P. and Judge, Timothy. (2019). Organizational Behavior. USA. America: Pearson Education, Inc. ISBN 13: 978-0-13-472932-9. (Google)

Schermerhorn, John R . (2012). Organizational Behavior, 12th Edition Hoboken NJ.: John Wiley \& Sons, Inc. (Google).

Tambunan, Susi Marta. ((2019). Pengaruh Baya Kepemimpinan Terhadap Kinerja Karyawan Pada Restauran O’Flahertys Medan. Jurnal Mutiara Manajemen, Vol.4 No.2, 2019. e-ISSN : 2579-759X. http://ejournal.sari-mutiara.ac.id/index.php/JMM/article/download/952/779.

Tannandy (2018) Tannandy, Hendy (2018). Manajemen Sumber Daya Manusia. Expert ; Yogyakarta. (Google). Widyaningrum, Mahmudah Enny. (2010). Pengaruh Keadilan Organisasi Terhadap Kepuasan Kerja, Komitmen dan Organizational Citisenship Behavior Pegawai (Studi Kasus Di Rumah Sakit Bersalin Pura Raharja Surabaya). Jurnal JEBA (Majalah Ekonomi, Tahun XX, No. 1 April 2010). Vo;.20, No.1. 100-118. https://ejournal.unair.ac.id/JEBA/article/view/4280/2920. (Google Scholar). 